\title{
Gated Recurrent Units dalam Mendeteksi Obstructive Sleep Apnea
}

\author{
JASMAN PARDEDE, MUHAMMAD FAUZAN RASPATI \\ Program Studi Informatika, Institut Teknologi Nasional Bandung \\ Email: jasman@itenas.ac.id
}

Received 4 Agustus 2021 | Revised 16 November 2021 | Accepted 30 November 2021

\begin{abstract}
ABSTRAK
Dalam melakukan penelitian obstructive sleep apnea (OSA), polysomnography (PSG) digunakan untuk diagnosis. Namun subjek diharuskan menginap dilaboratorium selama beberapa malam untuk melakukan tes dengan PSG dan karena banyaknya alat yang harus dikenakan pada tubuh dapat membuat tidak nyaman saat pengambilan data. Belakangan ini, beberapa peneliti mengunakan single-lead ECG untuk melakukan deteksi OSA. Untuk menghasilkan model terbaik, akan dilakukan eksperimen training, dengan batch normalization dan dropout yang berbeda. Pada penelitian ini apnea-ecg dataset digunakan, RRInterval dan amplitudo QRS complex dari released set berjumlah 35 data akan disegmentasi permenit untuk digunakan sebagai input dari arsitektur yang diajukan adalah gated recurrent unit (GRU). Lalu withheld set berjumlah 35 data akan digunakan untuk pengujian per-segment dan per-recording. Kinerja sistem diukur berdasarkan accuracy, sensitifity, dan specificity dengan pengujian persegment mendapat hasil accuracy $83.92 \%$, sensitifity $81.28 \%$, dan specificity 85.55\%, dan pengujian per-recording mendapat hasil accuracy 97.14\%, sensitifity $95.65 \%$ dan specificity $100 \%$.
\end{abstract}

Kata kunci: Obstructive sleep apnea, GRU, ECG, RR-Interval, QRS complex.

\begin{abstract}
In conducting obstructive sleep apnea (OSA) studies, polysomnography (PSG) was used for the diagnosis. However, the subject was required to stay in the laboratory for several nights to carry out tests with the PSG and because of the many devices that had to be worn on the body, it could be uncomfortable to collect data. Recently, several researchers have used single-lead ECG to detect OSA. To produce the best model, training experiments will be conducted, with different batch normalization and dropout. In this study, the apnea-ecg dataset is used, the RR-Interval and the QRS complex amplitude from the released set totaling 35 data will be segmented per minute to be used as input for the proposed architecture is the gated recurrent unit (GRU). Then the withheld set of 35 data will be used for per-segment and per-recording testing. System performance was measured based on accuracy, sensitivity, and specificity with per-segment testing getting $83.92 \%$ accuracy, $81.28 \%$ sensitivity, and $85.55 \%$ specificity, and per-recording testing got 97.14\% accuracy, 95.65\% sensitivity and $100 \%$ specificity.
\end{abstract}


Keywords: Obstructive sleep apnea, GRU, ECG, RR-Interval, QRS complex. 


\section{PENDAhUlUAN}

Salah satu gangguan tidur yang paling sering ditemukan adalah sleep apnea (henti nafas pada waktu tidur). Beberapa gejala dari sleep apnea berupa rasa tercekik ketika tidur, nafas terengah-engah, mengantuk dipagi hari, hilangnya konsentrasi, dan gejala yang paling sering timbul pada sleep apnea adalah mendengkur. Mendengkur (snoring) adalah suara bising yang disebabkan oleh aliran udara melalui sumbatan saluran nafas pada bagian belakang hidung dan mulut yang terjadi saat tidur. Sleep apnea ditandai dengan kolaps berulang dari saluran nafas atas (Darmadi, Rizal, Sunarya, 2015). Pada 35-45\% pria dan $15-28 \%$ wanita memiliki kebiasaan mendengkur. Akan tetapi, tidak semua orang yang mempunyai kebiasaan mendengkur menderita OSA (Purwowiyoto, 2018). Pengaruh buruk dari mendengkur dapat mengakibatkan dampak yang serius seperti peningkatan risiko terjadinya tekanan darah tinggi, serangan jantung, stroke, depresi berat, sulit konsentrasi, frustasi, dan sering marah. Kualitas tidur yang tidak baik disebabkan oleh mendengkur juga dapat menyebabkan seseorang menjadi sering mengantuk saat beraktivitas.

Untuk melakukan sebuah diagnosis OSA, dilakukan full night polysomnography (PSG) pada laboratorium tidur (Wang, 2019). PSG melakukan rekaman minimal sebelas sinyal fisiologis yang dikumpulkan dari berbagai sensor, beberapa diantaranya adalah electrocardiogram (ECG), electromyogram (EMG), electroencephalogram (EEG), electrooculography (EOG), dan sinyal pernafasan (Song, 2016). Dimana sensor ini digunakan pada tubuh yang akan melakukan diagnosis OSA, sehingga membuat sedikit tidak nyaman saat hendak tidur. Ukuran keparahan dari OSA dapat dilihat dari AHI (apnea-hypopnea index), kriteria AHI berdasarkan standar adalah $\mathrm{AHI}<5$ diindikasikan sebagai kondisi normal, AHI $15-30$ sebagai kategori ringan, AHI > 30 diindikasikan sebagai kategori berat (Hudgel, 2016).

Beberapa penelitian mengenai OSA dengan menggunakan dataset apnea-ecg dari physionet sebelumnya pernah dilakukan. Pada tahun 2015 Carolina Varon (Varon, 2015) melakukan penelitian single-lead ECG yang disegmentasi permenit untuk deteksi sleep apnea menggunakan dua fitur yang berasal dari sinyal ECG yaitu QRS complex dan RR-interval (RRI), klasifikasi menggunakan LS-SVM. Pada tahun 2016 Changyue Song (Song, 2016) melakukan penelitian single-lead ECG dengan 2 ekstrasi fitur yaitu RRI dan sinyal EDR dan data disegmentasi permenit, proses klasifikasi menggunakan metode HMM-SVM. Tao Wang (Wang, 2019) pada 2019 melakukan penelitian OSA dengan fitur otomatis dari RRI dan amplitude, dalam melakukan klasifikasinya menggunakan arsitektur LeNet-5. Lalu pada tahun 2021 Haifa Almutairi (Almutairi, Hassan, Datta, 2021) melakukan penelitian OSA menggunakan ekstrasi fitur dari RRI dan QRS amplitude, $k$-fold cross validation digunakan untuk data dan CNN-LSTM digunakan untuk klasifikasi.

Pada penelitian ini, akan melakukan deteksi OSA menggunakan sinyal ECG yang akan dilakukan preprocessing dengan melakukan ekstrasi fitur frekuensi domain dari RRI dan amplitude QRS complex, proses klasifikasi menggunakan recurrent neural network dengan arsitektur gated recurrent unit (GRU), dan untuk mengukur kinerja sistem akan menggunakan confusion-matrix, dengan menghitung accuracy, sensitifity, dan spesificity. Dataset yang digunakan dalam penelitian ini berasal dari Dr. Thomas Penzel dari PhillipsUniversity, Marburg, Jerman.

\section{METODE PENELITIAN}

Pada penelitian ini, masukan untuk sistem berupa data sinyal ECG dengan format .dat, .apn, dan .qrs yang didapatkan dari Physionet. Data ini akan melalui tahapan pre-processing, training, dan testing. 


\subsection{Gated Recurrent Unit}

Gated recurrent unit merupakan salah satu varian dari recurrent neural network yang dibuat untuk membuat setiap recurrent unit dapat menangkap dependencies dengan skala waktu yang berbeda - beda secara adaptive (Chung, 2014), dan juga untuk mengatasi masalah vanishing gradient (Shen, 2018). Gambar 1 merupakan arsitektur dari GRU.

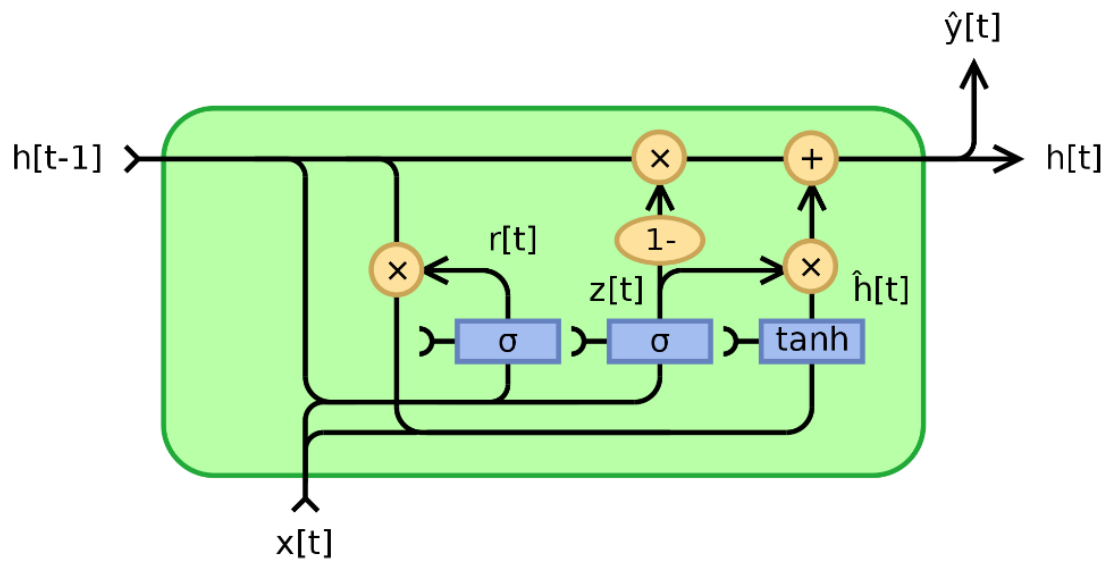

Gambar 1. Arsitektur Gated Recurrent Unit

LSTM
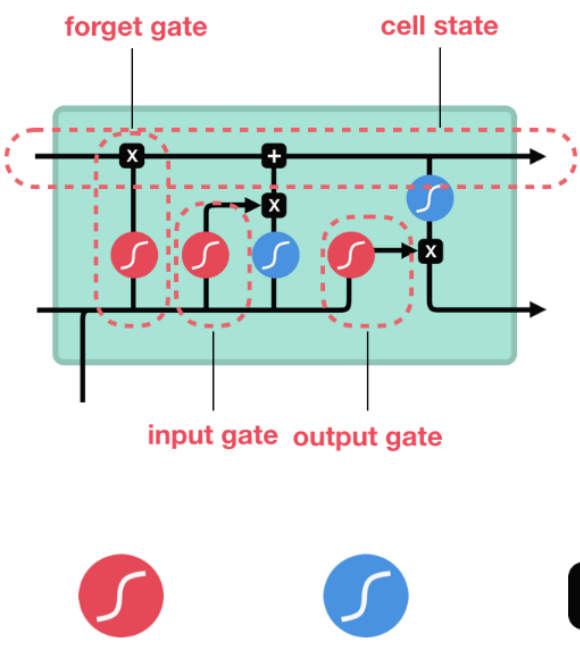

sigmoid

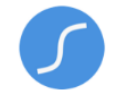

tanh

\section{$\mathbf{x}$}

pointwise multiplication
GRU

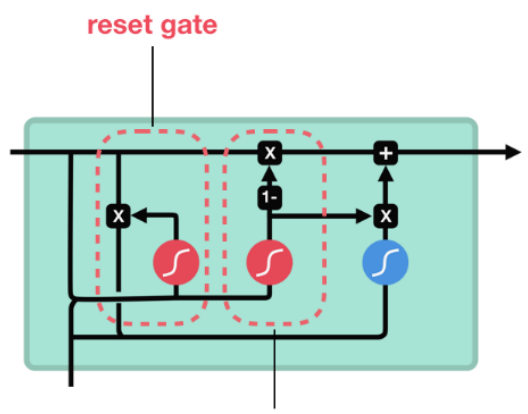

update gate

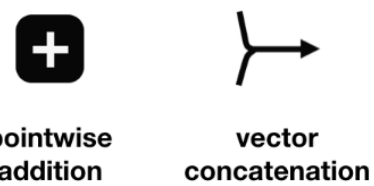

\section{Gambar 2. Arsitektur LSTM(Kiri) dan GRU(Kanan)}

GRU merupakan variasi yang lebih sederhana dari varian lainnya, yaitu long short term memory (LSTM). Gambar 2 merupakan ilustrasi dari arsitektur GRU dan LSTM. GRU merupakan salah satu arsitektur yang didesain untuk mengatasi masalah data sekuens atau time-series (Le, 2019). GRU memiliki tiga gerbang dalam melakukan komputasi yaitu update gate pada Persamaan 1 untuk membantu model menentukan berapa banyak informasi yang perlu dilanjutkan ke tahap selanjutnya, reset gate pada Persamaan 2 untuk memutuskan berapa banyak informasi sebelumnya yang akan dilupakan, current memory content pada Persamaan 3 dimana akan menggunakan reset gate untuk menyimpan informasi yang relevan dari masa lalu, dan final memory pada Persamaan 4 yang 
menggunakan update gate untuk menyimpan informasi untuk unit saat ini dan informasi dari langkah sebelumnya untuk diteruskan ke jaringan selanjutnya.

$$
\begin{aligned}
& z_{t}=\sigma\left(W_{z} x_{t}+U_{z} h_{t-1}+b_{z}\right) \\
& r_{t}=\sigma\left(W_{r} x_{t}+U_{r} h_{t-1}+b_{r}\right) \\
& \tilde{h}=\tanh \left(W_{h} x_{i}+r_{h} * U_{h} h_{t-1}+b_{h}\right) \\
& h_{t}=z_{t} * h_{(t-1)}+\left(1-z_{t}\right) * \tilde{h}
\end{aligned}
$$

Keterangan:

$z=$ Update gate

$r=$ Reset gate

$\tilde{h}=$ Current memory content

$h=$ Final memory

$\sigma=$ Fungsi aktivasi sigmoid

$$
\begin{aligned}
& \text { Tanh = Fungsi aktivasi tanh } \\
& W=\text { Bobot } \\
& x_{t}=\text { Input } \\
& U=\text { hidden state } \\
& b=\text { Bias vector }
\end{aligned}
$$

Untuk mekanisme dari gerbang GRU dimana $z, r, \tilde{h}$, dan $h$ adalah update gate, reset gate, current memory content, dan final memory. Untuk $\sigma$ dan tanh merepresentasikan fungsi aktivasi yang digunakan pada GRU. $x_{t}$ merupakan input ke layer pada waktu $t$. Dan untuk $W, U$, dan $b$ merupakan bobot, hidden state, dan bias vector.

\subsection{Dataset}

Pada penelitian ini, dataset yang digunakan adalah apnea-ecg dari physionet. Terdapat 70 rekaman ECG pada dataset ini dengan durasi yang bervariasi, mulai dari 401 menit hingga 578 menit (Penzel, 2000). Rekaman ini memiliki resolusi 16-bit dan rekaman diambil sampelnya pada $100 \mathrm{~Hz}$. Rekaman ini dilakukan segmentasi 1 menit dan diberi label "normal" (N) dan "apnea" (A) oleh ahlinya (Li, 2018). Rekaman ECG ini terdiri dari 2 set dimana masing - masingnya berisi 35 rekaman. Set pertama (released set) digunakan untuk membangun model dan memvalidasi model dan set kedua (withheld set) digunakan untuk menguji model.
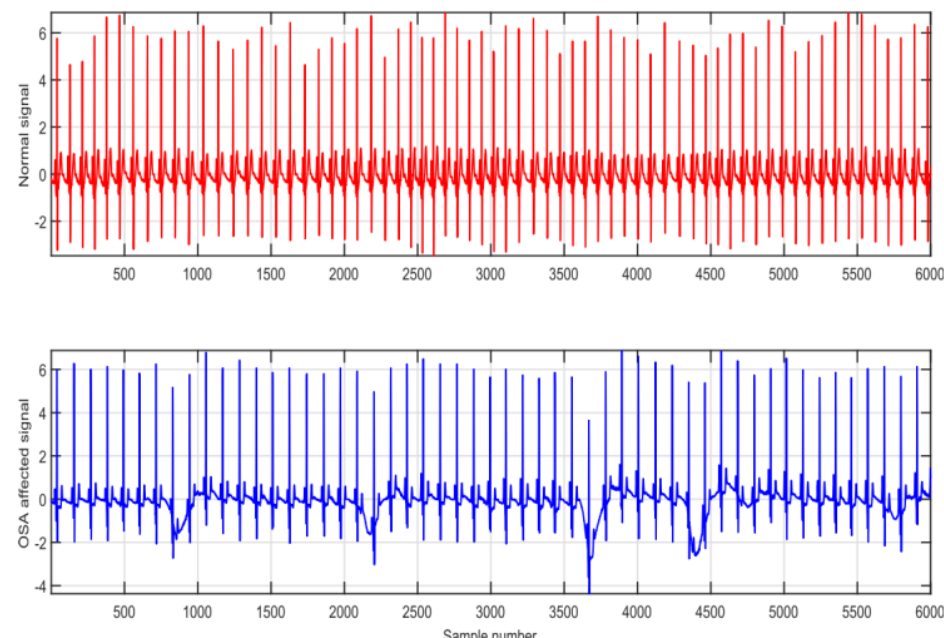

Gambar 3. Normal(atas) dan Apnea(bawah)

Terdapat beberapa file yang saling terhubung pada setiap rekaman, .hea merupakan informasi mengenai nama dan format dari rekaman, .apn berisi anotasi untuk setiap menit 
dari rekaman yang menunjukan ada atau tidaknya apnea pada setiap menitnya, .qrs berisi anotasi QRS complex pada sinyal ECG, dan .dat berisi ECG sinyal. Karena durasi rekaman ECG yang bervariasi, membuat kelas yang terdapat pada dataset ini memiliki jumlah yang berbeda. Sehingga dataset yang ini menjadi imbalance, dimana jumlah salah satu kelas lebih banyak daripada kelas yang lainnya (Kulkarni, Chong, Batarseh, 2020). Berikut merupakan cuplikan dan visualisasi salah satu rekaman ECG dengan ekstensi .dat dari dataset yang digunakan.

\begin{tabular}{|cccccccc|}
\hline Time & ECG $(\mathbf{m V})$ & Time & ECG $(\mathbf{m V})$ & Time & ECG $(\mathbf{m V})$ & Time & ECG $(\mathbf{m V})$ \\
$0: 00.000$ & -0.005 & $0: 00.280$ & -0.035 & $0: 00.560$ & -0.180 & $0: 00.840$ & 0.520 \\
$0: 00.010$ & 0.005 & $0: 00.290$ & -0.080 & $0: 00.570$ & -0.135 & $0: 00.850$ & 0.410 \\
$0: 00.020$ & 0.045 & $0: 00.300$ & -0.080 & $0: 00.580$ & 0.725 & $0: 00.860$ & 0.265 \\
$0: 00.030$ & 0.100 & $0: 00.310$ & -0.030 & $0: 00.590$ & 1.815 & $0: 00.870$ & 0.130 \\
$0: 00.040$ & 0.160 & $0: 00.320$ & -0.100 & $0: 00.600$ & 0.530 & $0: 00.880$ & 0.005 \\
$0: 00.050$ & 0.220 & $0: 00.330$ & -0.095 & $0: 00.610$ & -0.620 & $0: 00.890$ & -0.025 \\
$0: 00.060$ & 0.335 & $0: 00.340$ & -0.035 & $0: 00.620$ & -0.770 & $0: 00.900$ & -0.040 \\
$0: 00.070$ & 0.425 & $0: 00.350$ & -0.080 & $0: 00.630$ & -0.695 & $0: 00.910$ & -0.075 \\
$0: 00.080$ & 0.480 & $0: 00.360$ & -0.080 & $0: 00.640$ & -0.430 & $0: 00.920$ & -0.035 \\
$0: 00.090$ & 0.560 & $0: 00.370$ & -0.105 & $0: 00.650$ & -0.295 & $0: 00.930$ & -0.090 \\
$0: 00.100$ & 0.565 & $0: 00.380$ & -0.090 & $0: 00.660$ & -0.200 & $0: 00.940$ & -0.070 \\
$0: 00.110$ & 0.495 & $0: 00.390$ & -0.100 & $0: 00.670$ & -0.120 & $0: 00.950$ & -0.115 \\
$0: 00.120$ & 0.360 & $0: 00.400$ & -0.065 & $0: 00.680$ & -0.085 & $0: 00.960$ & -0.085 \\
$0: 00.130$ & 0.225 & $0: 00.410$ & -0.130 & $0: 00.690$ & -0.115 & $0: 00.970$ & -0.130 \\
$0: 00.140$ & 0.090 & $0: 00.420$ & -0.035 & $0: 00.700$ & -0.070 & $0: 00.980$ & -0.070 \\
$0: 00.150$ & 0.005 & $0: 00.430$ & 0.020 & $0: 00.710$ & -0.050 & $0: 00.990$ & -0.090 \\
$0: 00.160$ & -0.020 & $0: 00.440$ & 0.020 & $0: 00.720$ & -0.040 & & \\
$0: 00.170$ & -0.020 & $0: 00.450$ & 0.070 & $0: 00.730$ & -0.090 & & \\
$0: 00.180$ & -0.045 & $0: 00.460$ & 0.065 & $0: 00.740$ & 0.005 & & \\
$0: 00.190$ & -0.040 & $0: 00.470$ & -0.015 & $0: 00.750$ & 0.035 & & \\
$0: 00.200$ & -0.050 & $0: 00.480$ & -0.035 & $0: 00.760$ & 0.045 & & \\
$0: 00.210$ & -0.050 & $0: 00.490$ & -0.080 & $0: 00.770$ & 0.110 & & \\
$0: 00.220$ & -0.085 & $0: 00.500$ & -0.095 & $0: 00.780$ & 0.170 & & \\
$0: 00.230$ & -0.080 & $0: 00.510$ & -0.150 & $0: 00.790$ & 0.240 & & \\
$0: 00.240$ & -0.095 & $0: 00.520$ & -0.160 & $0: 00.800$ & 0.330 & & \\
$0: 00.250$ & -0.050 & $0: 00.530$ & -0.175 & $0: 00.810$ & 0.460 & & \\
$0: 00.260$ & -0.050 & $0: 00.540$ & -0.190 & $0: 00.820$ & 0.485 & & \\
$0: 00.270$ & -0.085 & $0: 00.550$ & -0.160 & $0: 00.830$ & 0.580 & & \\
& & & & & & & \\
& & & & & & & \\
\hline
\end{tabular}

Gambar 4. Cuplikan Data Selama 1 Detik

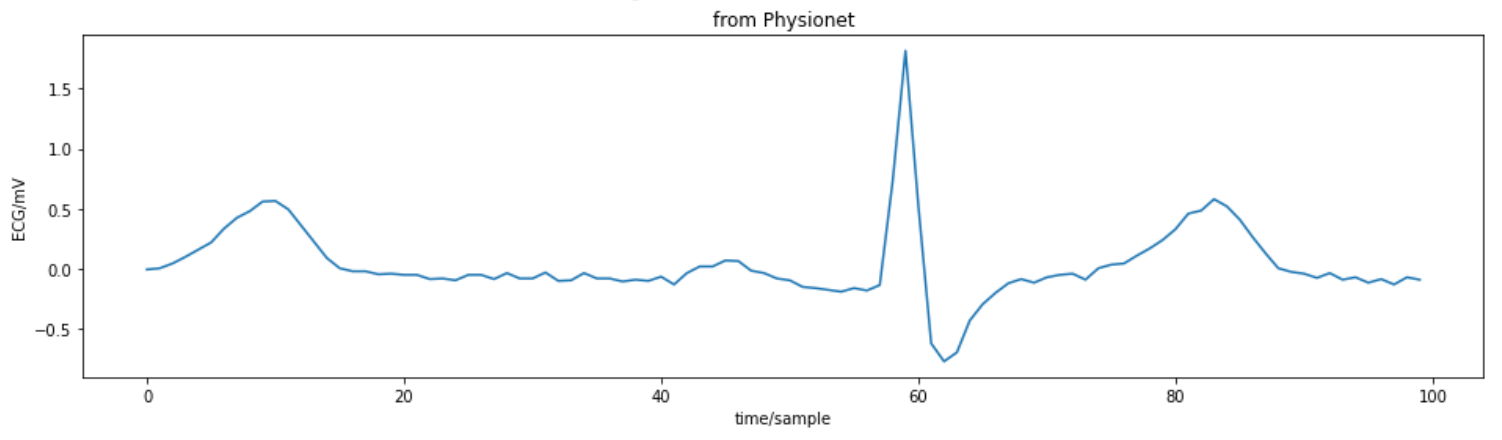

Gambar 5. Visualisasi data selama 1 detik

\subsection{Perancangan Sistem}

Bagian ini memaparkan proses perancangan sistem deteksi obstructive sleep apnea dengan metode gated recurrent unit. Gambar 6 merupakan blok diagram secara keseluruhan. 


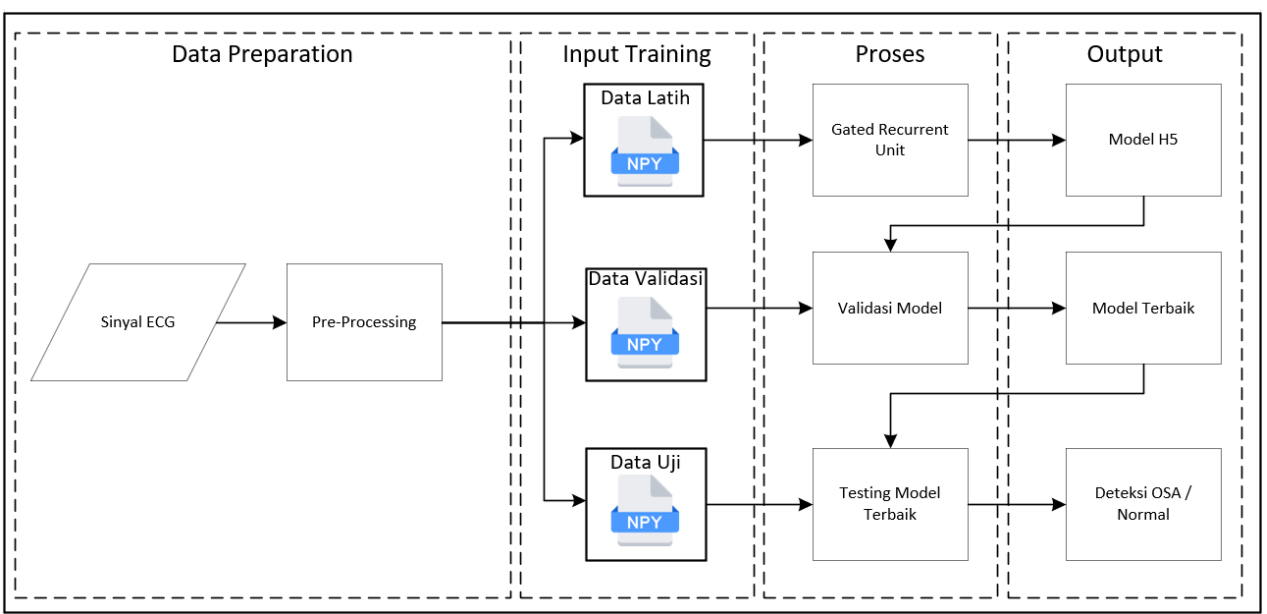

Gambar 6. Blok Diagram Sistem

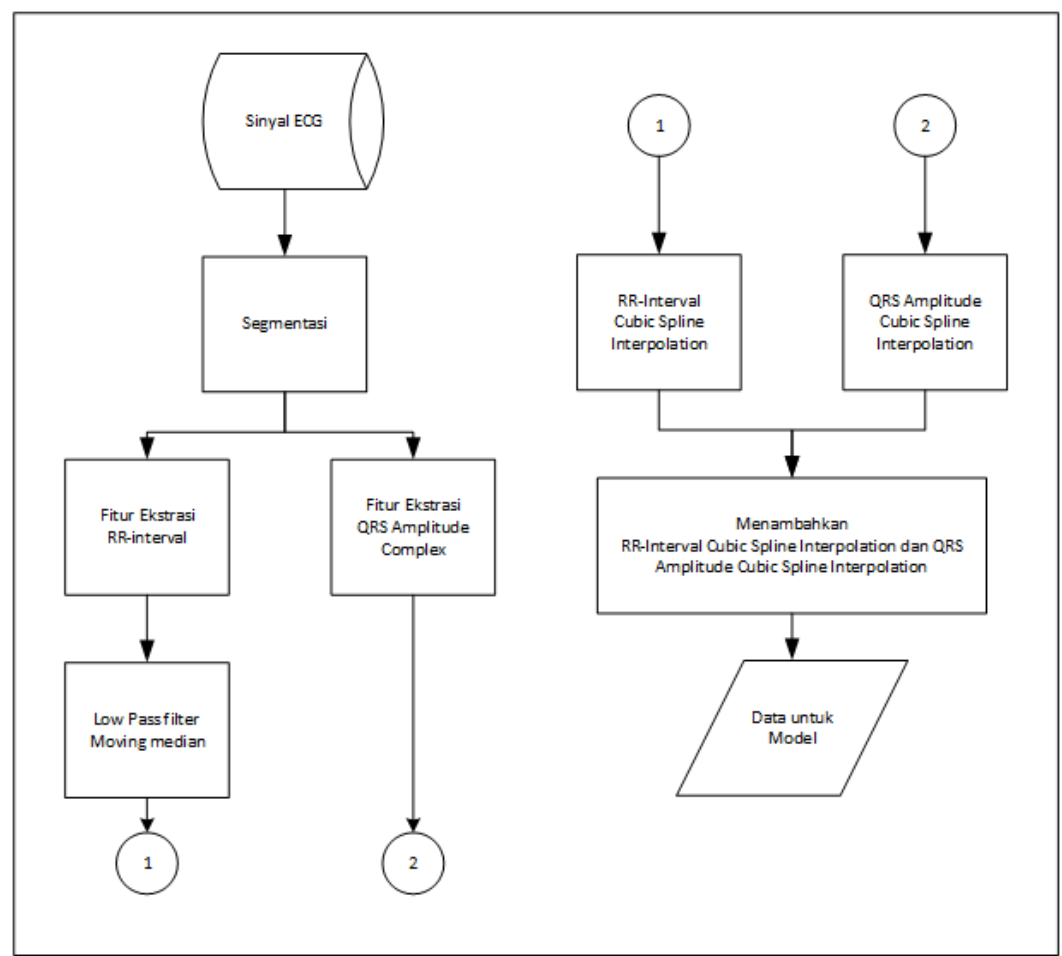

Gambar 7. Blok Diagram Pre-Processing

Released set yang berjumlah 35 rekaman ECG disegmentasi menjadi 16461 menit, untuk withheld set yang berjumlah 35 rekaman ECG akan disegmentasi menjadi 16732 menit. Released set yang sudah disegmentasi akan dibagi menjadi $80 \%$ data latih dan $20 \%$ data validasi, dan untuk data tes akan menggunakan withheld set dengan 2 macam pengujian. Kemudian setiap data akan dilakukan pre-processing untuk mendapatkan nilai - nilai yang dibutuhkan. Sebelum melakukan deteksi OSA, akan dilakukan pelatihan menggunakan metode GRU dengan data latih dan data validasi, keluaran hasil pelatihan ini menghasilkan model dengan format .h5, dengan data validasi yang akan mengukur kinerja model hingga menghasilkan model terbaik yang akan digunakan untuk testing. Data tes yang sudah disiapkan dan melalui tahap pre-processing akan digunakan untuk testing terhadap model terbaik yang dihasilkan, hingga output dari data tes ini adalah deteksi OSA. 


\subsection{Pre-Processing}

Tahapan pre-processing pada Gambar 8, akan mengekstraksi interval waktu antara detak jantung secara berturut - turut untuk mendapatkan $R R$-Interval. Proses ekstrasi yang pertama adalah mendapatkan nilai $R R$-interval. RR-interval adalah jarak dari 2 QRS complex (QRS[n] - QRS[1-n]), dan domain waktu dari RR-interval adalah titik tengah dari $Q R S$ complex.

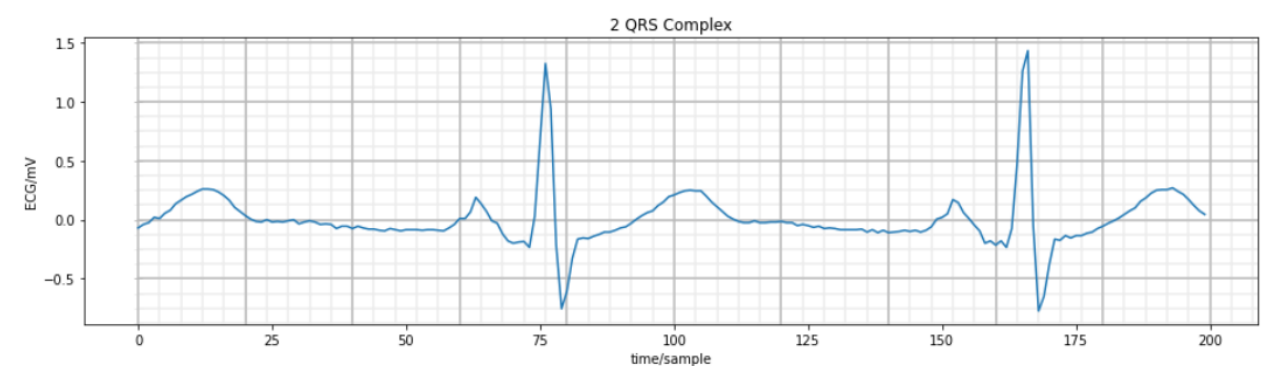

Gambar 8. QRS Complex pada Sinyal ECG
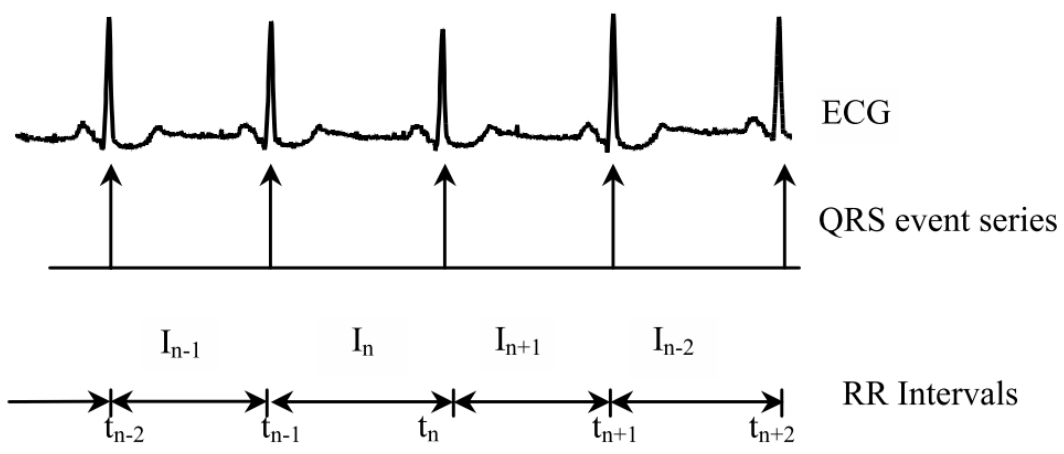

\section{Gambar 9. Ilustrasi ECG dengan QRS dan RR Interval (Singh, Vinod, Saxena 2004)}

Untuk beberapa kasus, nilai $R R$-interval akan muncul dengan nilai yang tidak diinginkan sehingga akan menimbulkan hasil yang tidak sempurna, maka akan dilakukan low-pass filter untuk menghilangkan derau menggunakan moving median. RR-interval yang sudah didapatkan akan dilakukan cubic spline interpolation untuk menghilangkan interval palsu (Almutairi et al., 2021).

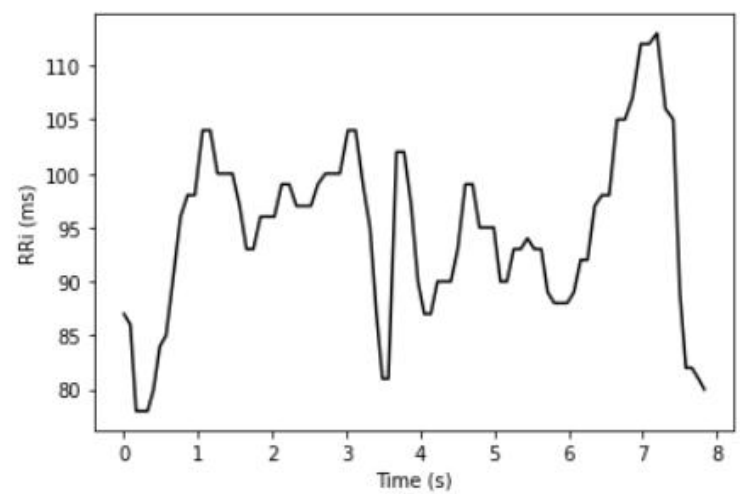

Gambar 10. Plot RR-interval dari Domain Waktu

Setelah dilakukan cubic spline interpolation, nilai akan dilakukan batchnormalization yang berguna untuk mempercepat proses training dan meningkatkan learning rates pada saat pembuatan model. Batchnormalization berkerja dengan menyamakan distribusi pada setiap 
nilai input yang selalu berubah - ubah dikarenakan perubahan parameter pada layer sebelumnya selama proses training (Ioffe, Szegedy, 2016).

\subsection{Training}

Proses ini merupakan pembuatan model dengan arsitektur GRU. Data latih dan data validasi akan melalui tahapan ini, dimana akan melakukan training menggunakan metode GRU dengan parameter seperti pada Tabel 1.

Tabel 1. Parameter Model

\begin{tabular}{|c|c|c|c|}
\hline Epoch & Optimizer & Learning rate & Dropout \\
\hline \multirow{3}{*}{100} & \multirow{3}{*}{ Adam } & & 0.1 \\
& & \multirow{3}{*}{0.0005} & 0.2 \\
\cline { 3 - 3 } & & & 0.3 \\
\cline { 3 - 3 } & & & 0.4 \\
\hline
\end{tabular}

Pada penelitian ini terdapat beberapa parameter yang digunakan, epoch digunakan sebagai penanda berapa kali model melakukan perulangan pada data latih secara keseluruhan. Optimizer yang digunakan pada pembuatan model ini adalah adam. Adam pertama kali dipresentasikan pada ICLR 2015 oleh Diederik P.Kingma dan Jimmi Lei Ba (Kingma, Ba, 2015). Pada beberapa penelitian, optimizer adam memiliki hasil yang baik dibandingkan dengan optimizer lainnya (Brownlee, 2017). Dalam mengatasi perbedaan jumlah class dari apnea dan normal, regularisasi dropout dijadikan eksperimen dalam menghasilkan model terbaik, karena dropout merupakan salah satu cara untuk menghindari overfitting (Srivastava, 1993).

\subsection{Testing}

Pada tahap ini akan dilakukan 2 macam pengujian, dengan melakukan pengujian persegment dan per-recording. Pengujian per-segment dilakukan untuk menguji kinerja sistem secara keseluruhan karena menggunakan keseluruhan rekaman yang disegmentasi permenit dan juga memberi dasar yang kuat untuk melakukan diagnosis seseorang yang dicurigai OSA (Wang, 2019). Sebuah rekaman ECG terdiri dari beberapa segmentasi permenit, dan untuk klasifikasi setiap rekaman berdasarkan pada keseluruhan segmentasi permenit, maka dilakukan pengujian per-recording untuk melakukan deteksi OSA. AHI akan digunakan untuk membedakan mana rekaman yang OSA dan normal pada pengujian per-recording. Jika AHI > 5 maka akan dideteksi sebagai OSA dan jika kurang akan dideteksi sebagai normal. Karena setiap segmentasi permenit memiliki label OSA atau normal, maka perkiraan jumlah menit dengan OSA per jam dapat dihitung sebagai berikut:

$$
A H I=\frac{60}{T} * \text { jumlah segmentasi OSA }
$$

Dimana $T$ merupakan jumlah menit segmentasi rekaman ECG, $T$ /60 merupakan jumlah jam dari segmentasi rekaman ECG, lalu akan dikalikan dengan jumlah segmentasi OSA. Nilai AHI ini nantinya akan dibandingkan dengan nilai AHI yang sebenarnya dari dataset untuk menentukan rekaman ECG tersebut OSA atau normal. Tahapan testing seperti pada Gambar 11. 


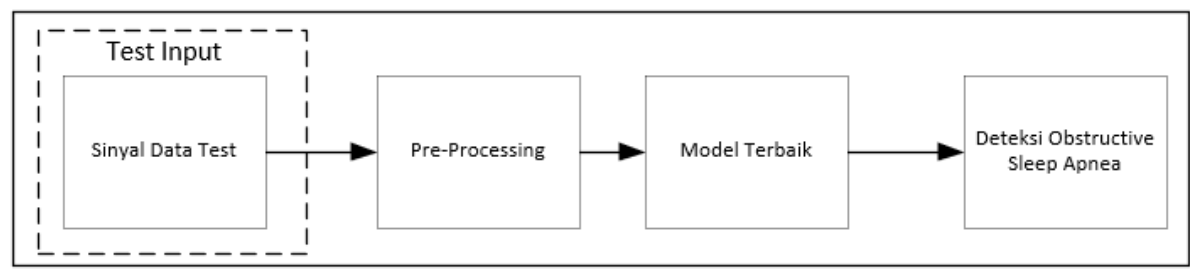

Gambar 11. Tahapan Testing

\subsection{Evaluasi}

Evaluasi dalam mengukur kinerja sistem ini, mengukur accuracy, sensitifity, dan specificity dengan confusion matrix. Dalam melakukan diagnosis sebuah penyakit, sensitifity dan specificity biasa digunakan untuk evaluasi kinerja sistem. Confusion matrix merupakan ukuran yang biasa digunakan dalam memecahkan masalah binary classification dan masalah multiclass classification (Kulkarni, Chong, Batarseh, 2020). Sensitivity merupakan persentase true positive dengan kondisi OSA, dan specificity merupakan persentase true negative dengan kondisi normal (Bolin, Lam, 2013). Tabel 2 merupakan confusion matrix untuk binary classification.

Tabel 2. Confusion Matrix

\begin{tabular}{|c|c|c|c|}
\hline \multirow{4}{*}{$\frac{\pi}{\mathbb{Z}}$} & \multicolumn{3}{|c|}{ Predicted } \\
\hline & & Negative & Positive \\
\hline & Negative & TN & FP \\
\hline & Positive & FN & TP \\
\hline
\end{tabular}

$$
\begin{aligned}
& \text { Accuracy }=\frac{T P+T N}{T P+F P+T N+F N} \\
& \text { Sensitivity }=\frac{T P}{T P+F N} \\
& \text { Specificity }=\frac{T N}{T N+F P}
\end{aligned}
$$

Keterangan :

- $\mathrm{TP}=$ Jumlah class apnea yang terprediksi apnea.

- $\mathrm{TN}=$ Jumlah class normal yang terprediksi normal.

- $\mathrm{FP}=$ Jumlah class normal yang terprediksi apnea.

- $\mathrm{FN}=$ Jumlah class apnea yang terprediksi normal.

Pada penelitian ini hasil dari TP merupakan "true positive" dimana data positif yang terprediksi benar, subjek yang OSA terprediksi memiliki OSA. Untuk FP merupakan "false positive" dimana data negative terprediksi sebagai data positive, subjek yang normal terprediksi memiliki OSA. Begitupun sebaliknya, untuk TN merupakan "true negative" dimana data negative yang terprediksi benar, subjek normal terprediksi normal. Untuk FN merupakan "false negative" dimana data positive terprediksi sebagai data negative, subjek yang OSA terprediksi normal.

\section{HASIL DAN PEMBAHASAN}


Penelitian ini dilakukan menggunakan produk dari Google Research yaitu Google Colab (Colab) untuk membantu proses training, spesifikasi yang disediakan untuk colab pro yaitu menggunakan Graphic Processing Unit (GPU) Tesla P100. Untuk testing menggunakan processor Intel Core i7-5500U @2.40GHz, Random Access Memory (RAM) 8 GB, GPU Nvidia GeForce GTX 850M. Hasil penelitian ini akan dituangkan dan dijabarkan pada bagian ini. Sistem ini dibangun menggunakan bahasa pemrograman Python 3.8 dengan menggunakan library dari Tensorflow 2.5, dalam mengolah sinyal ECG menggunakan library waveformdatabase (WFDB) dan library heart rate variability (HRV).

\subsection{Training}

Untuk mendapatkan model terbaik dari arsitektur GRU, dilakukan pelatihan model dengan menggunakan released set yang telah dibagi menjadi $80 \%$ data latih dan $20 \%$ data validasi. Layer yang digunakan untuk membangun model terdapat pada Tabel 3.

Tabel 3. Struktur Model

\begin{tabular}{|c|c|c|}
\hline No & Layer & Unit \\
\hline 1. & Batchnormalization & - \\
\hline 2. & GRU & 64 \\
\hline 3. & GRU 1 & 128 \\
\hline 4. & Dense & 64 \\
\hline 5. & Dense 1 & 1 \\
\hline
\end{tabular}

Eksperimen dilakukan menggunakan dropout 0.1, 0.2, 0.3, 0.4, dan 0.5, 100 epoch, 128 batch size, optimizer Adam, dan learning rate 0.0005. Gambar 10 dan Gambar 11 merupakan hasil accuracy dan loss dari eksperimen training. Dimana sumbu $\mathrm{x}$ merupakan jumlah epoch yang digunakan dan sumbu y merupakan informasi accuracy dan loss.

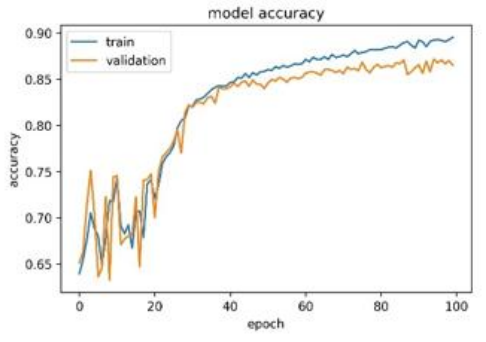

Dropout 0.1

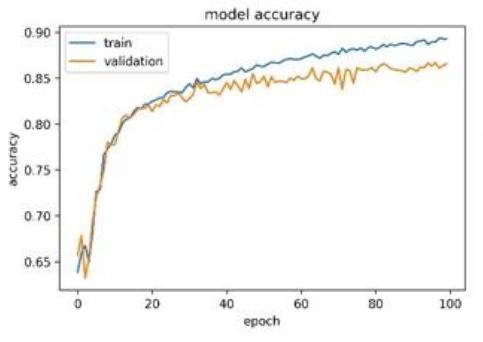

Dropout 0.2

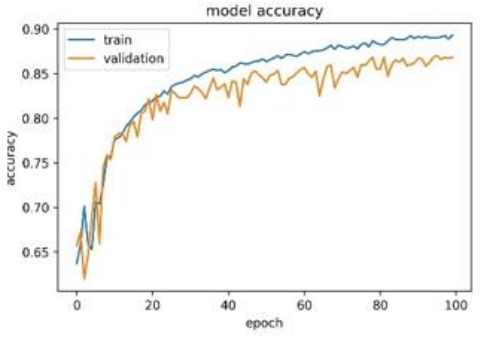

Dropout 0.3

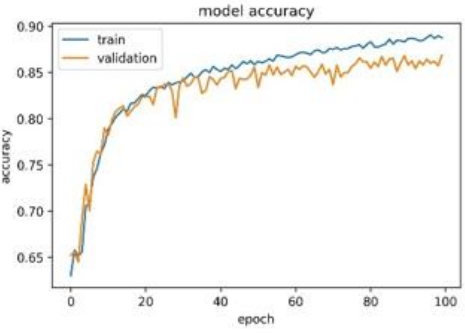

Dropout 0.4

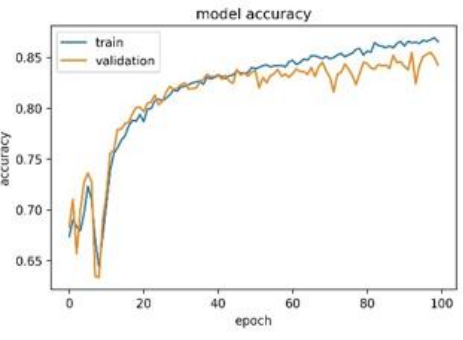

Dropout 0.5

Gambar 12. Accuracy untuk Dropout yang Berbeda 


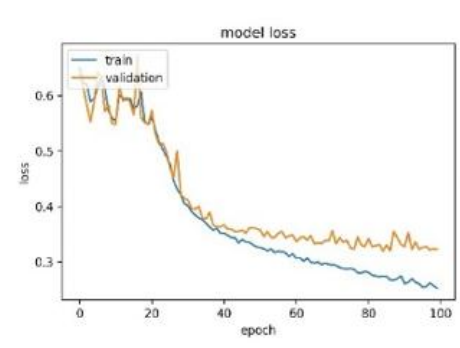

Dropout 0.1

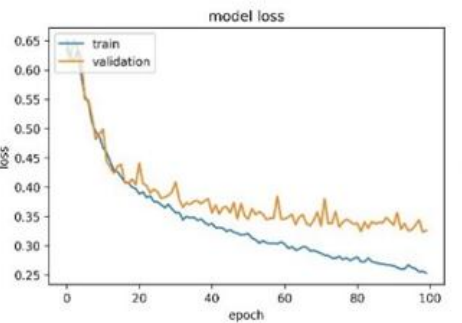

Dropout 0.2

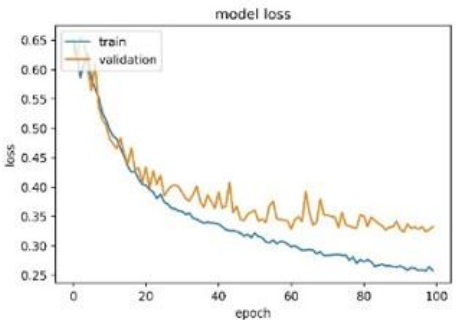

Dropout 0.3

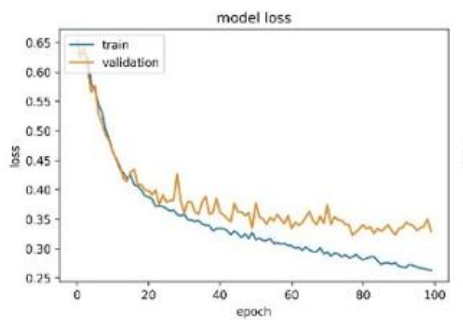

Dropout 0.4

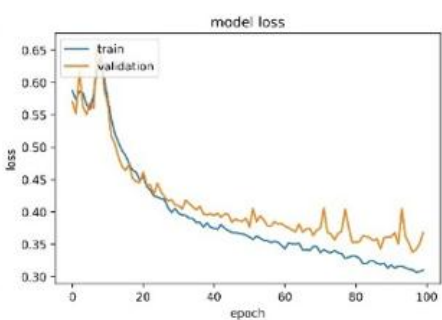

Dropout 0.5

\section{Gambar 13. Loss untuk Dropout yang berbeda}

Dari grafik yang ditampilkan pada Gambar 10 dan Gambar 11, memperlihatkan perubahan accuracy dan loss saat proses training dengan dropout yang berbeda. Seluruh model akan digunakan pengujian untuk mengetahui pada dropout berapa yang menghasilkan model terbaik.

\subsection{Pengujian}

Pengujian terhadap model terbaik akan dilakukan dengan 2 cara, yaitu pengujian persegment dan per-recording.

\subsubsection{Pengujian Per-Segment}

Pada pengujian per-segment akan menggunakan $20 \%$ data dari withheld set yang telah disegmentasi menjadi 16732. Sebanyak 3347 data dari withheld set secara acak akan digunakan untuk pengujian per-segment. Dengan mengukur kinerja arsitektur GRU menggunakan confusion-matrix dimana mengukur kinerja sistem secara keseluruhan berdasarkan accuracy, sensitivity dan specificity dihitung menggunakan Persamaan (6), (7), dan (8). Pada Gambar 12 merupakan hasil confusion-matrix dari 3347 data test yang digunakan, dan Tabel 4 merupakan perbandingan dari setiap model.

Tabel 4. Perbandingan setiap Model

\begin{tabular}{|c|c|c|c|}
\hline Model & Accuracy & Sensitifity & Specificity \\
\hline Model 1 & $81.23 \%$ & $71.55 \%$ & $87.20 \%$ \\
\hline Model 2 & $83.92 \%$ & $81.28 \%$ & $85.55 \%$ \\
\hline Model 3 & $80.99 \%$ & $80.09 \%$ & $81.55 \%$ \\
\hline Model 4 & $80.16 \%$ & $77.74 \%$ & $81.65 \%$ \\
\hline Model 5 & $80.90 \%$ & $71.78 \%$ & $86.52 \%$ \\
\hline
\end{tabular}



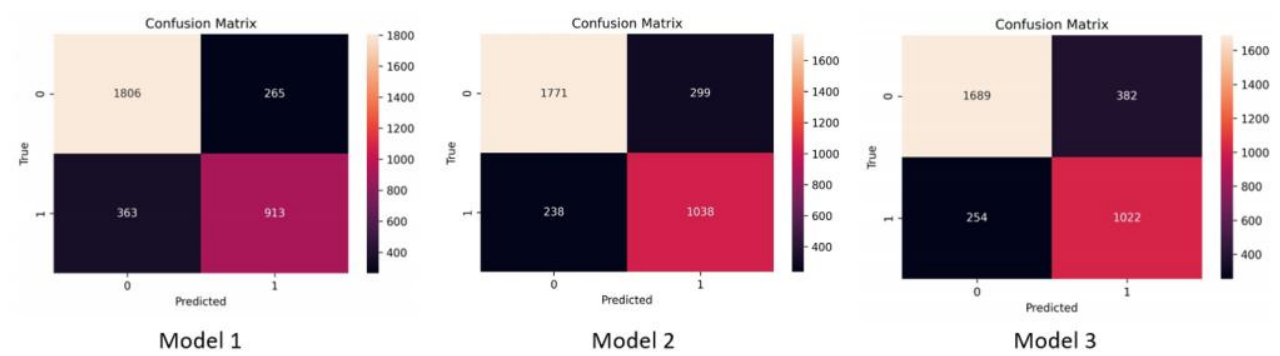

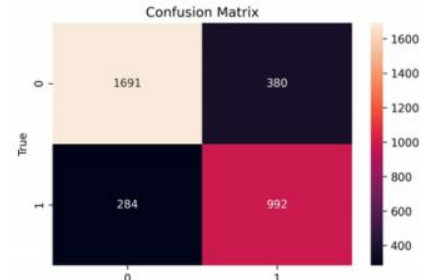

Predicted

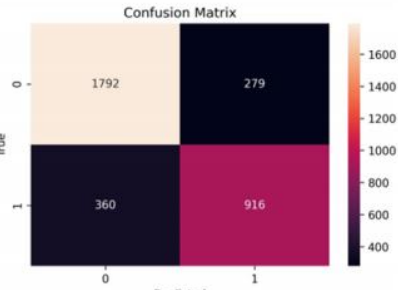

Model 5

\section{Gambar 14. Confusion-matrix Data Test pada setiap Model}

Berdasarkan hasil pengujian per-segment dengan data tes, menunjukan bahwa model 2 memiliki accuracy dan sensitifity yang tinggi. Sensitifity yang tinggi penting untuk menjadi acuan dalam deteksi sebuah penyakit, karena memiliki hasil true positive yang tinggi. Maka model 2 akan digunakan untuk melakukan pengujian per-recording untuk deteksi OSA.

\subsubsection{Pengujian Per-Recording}

Untuk mendeteksi OSA atau normal akan menggunakan withheld set yang berjumlah 35 rekaman (x01 - x35). Nilai AHI akan digunakan untuk diagnosis. Perbandingan nilai AHI yang tersedia dengan hasil prediksi nilai AHI terdapat pada Tabel 5.

Tabel 5. Hasil Per-Recording untuk x01-x35

\begin{tabular}{|c|c|c|c|c|}
\hline \multirow{2}{*}{$\begin{array}{c}\text { Rekaman } \\
\text { ECG }\end{array}$} & \multicolumn{2}{|c|}{ Anotasi Oleh Ahli } & \multicolumn{2}{|c|}{ Model GRU } \\
\cline { 2 - 5 } & AHI & Deteksi & $\begin{array}{c}\text { AHI oleh } \\
\text { Sistem }\end{array}$ & Deteksi \\
\hline X01 & 63 & OSA & 36.2 & OSA \\
\hline X02 & 37.7 & OSA & 21.7 & OSA \\
\hline X03 & 0.13 & Normal & 0.64 & Normal \\
\hline X04 & 0 & Normal & 0 & Normal \\
\hline X05 & 34 & OSA & 33.9 & OSA \\
\hline X06 & 0 & Normal & 0 & Normal \\
\hline X07 & 21 & OSA & 24.6 & OSA \\
\hline X08 & 48 & OSA & 33.9 & OSA \\
\hline X09 & 18.5 & OSA & 14.7 & OSA \\
\hline X10 & 10 & OSA & 7.20 & OSA \\
\hline X11 & 5 & Normal & 0.92 & Normal \\
\hline X12 & 33 & OSA & 4.91 & Normal \\
\hline
\end{tabular}




\begin{tabular}{|c|c|c|c|c|}
\hline \multirow{2}{*}{$\begin{array}{c}\text { Rekaman } \\
\text { ECG }\end{array}$} & Anotasi Oleh Ahli & \multicolumn{2}{|c|}{ Model GRU } \\
\cline { 2 - 5 } & AHI & Deteksi & $\begin{array}{c}\text { AHI oleh } \\
\text { Sistem }\end{array}$ & Deteksi \\
\hline X13 & 18.7 & OSA & 21.9 & OSA \\
\hline X14 & 79.5 & OSA & 37.7 & OSA \\
\hline X15 & 15.9 & OSA & 12 & OSA \\
\hline X16 & 24 & OSA & 6.54 & OSA \\
\hline X17 & 0 & Normal & 0.17 & Normal \\
\hline X18 & 0 & Normal & 0 & Normal \\
\hline X19 & 56.2 & OSA & 47.5 & OSA \\
\hline X20 & 43 & OSA & 25.3 & OSA \\
\hline X21 & 19 & OSA & 12.8 & OSA \\
\hline X22 & 0 & Normal & 0 & Normal \\
\hline X23 & 14.3 & OSA & 12 & OSA \\
\hline X24 & 0 & Normal & 0 & Normal \\
\hline X25 & 48 & OSA & 32.8 & OSA \\
\hline X26 & 15.1 & OSA & 27.4 & OSA \\
\hline X27 & 75 & OSA & 53.5 & OSA \\
\hline X28 & 75 & OSA & 46.1 & OSA \\
\hline X29 & 0 & Normal & 0 & Normal \\
\hline X30 & 41 & OSA & 34.5 & OSA \\
\hline X31 & 93.5 & OSA & 37.6 & OSA \\
\hline X32 & 71.8 & OSA & 31.3 & OSA \\
\hline X33 & 0.13 & Normal & 0.12 & Normal \\
\hline X34 & 0.38 & Normal & 0.25 & Normal \\
\hline X35 & 0 & Normal & 0 & Normal \\
\hline
\end{tabular}

Tabel 6. Evaluasi Per-Recording

\begin{tabular}{|c|c|c|c|c|}
\hline \multirow{4}{*}{ 鸪 } & \multicolumn{3}{|c|}{ Predicted } & Pengukuran \\
\hline & & Negative & Positive & Accuracy $97.14 \%$ \\
\hline & Negative & 12 & $\mathbf{0}$ & Sensitivity $95.65 \%$ \\
\hline & Positive & 1 & 22 & Specificity $100 \%$ \\
\hline
\end{tabular}

Dari hasil evaluasi untuk deteksi OSA per-recording mendapatkan hasil akurasi $97.14 \%$, namun perlu diingatkan bahwa withheld set hanya memiliki 35 data, yang mengakibatkan pengujian per-segment mendapatkan hasil yang lebih rendah. 


\section{KESIMPULAN}

Pada penelitian ini, telah mengimplementasikan arsitektur GRU untuk melakukan deteksi OSA. Model GRU pada penelitian ini menggunakan 100 epoch, 128 batch size, optimizer Adam, dan learning rate 0.0005. Dalam melakukan optimasi model, early stopping pada proses training digunakan untuk menghentikan proses pelatihan ketika akurasi validasi tidak ada peningkatan selama 20 epoch. Regularisasi dari dropout digunakan untuk membantu mengurangi overfitting pada model. Hasil eksperimen pada dropout 0.2 mendapatkan hasil pengujian per-segmentasi terbaik dengan hasil accuracy $83.92 \%$, sensitifity $81.28 \%$, dan specificity $85.55 \%$. Untuk melakukan pengujian per-recording, 35 data dari withheld set digunakan untuk deteksi OSA, dengan hasil accuracy $97.14 \%$, sensitifity $95.65 \%$ dan specificity $100 \%$. Kedua pengujian yang dilakukan memperlihatkan bahwa penggunaan jumlah data dapat mempengaruhi hasil accuracy yang didapatkan, sehingga pengujian perrecording mendapatkan hasil yang lebih tinggi karena jumlah data yang digunakan tidak sebanyak pengujian per-segmentasi.

\section{DAFTAR RUJUKAN}

Almutairi, H., Hassan, G. M., \& Datta, A. (2021). Detection of obstructive sleep apnoea by ECG signals using deep learning architectures. European Signal Processing Conference, 2021-Janua, 1382-1386. https://doi.org/10.23919/Eusipco47968.2020.9287360

Bolin, E., \& Lam, W. (2013). A review of sensitivity, specificity, and likelihood ratios: Evaluating the utility of the electrocardiogram as a screening tool in hypertrophic cardiomyopathy. Congenital Heart Disease, 8(5), 406-410. https://doi.org/10.1111/chd.12083

Brownlee, J. (2017). Gentle Introduction to the Adam Optimization Algorithm for Deep Learning. Neural Networks. https://machinelearningmastery.com/adam-optimizationalgorithm-for-deep-learning/

Chung, J., Gulcehre, C., Cho, K., \& Bengio, Y. (2014). Empirical Evaluation of Gated Recurrent Neural Networks on Sequence Modeling. 1-9. http://arxiv.org/abs/1412.3555

Darmadi, F., Rizal, A., \& Sunarya, U. (2015). Deteksi Sleep Apnea Melalui Analisis Suara Dengkuran Dengan Metode Mel Frekuensi Cepstrum. 2(2), 2681-2686.

Hudgel, D. W. (2016). Sleep Apnea Severity Classification Revisited. Sleep, 39(5), 11651166. https://doi.org/10.5665/sleep.5776

Ioffe, S., \& Szegedy, C. (2016). Batch Normalization: Accelerating Deep Network Training by Reducing Internal Covariate Shift. Journalism Practice, 106), 730-743. https://doi.org/10.1080/17512786.2015.1058180

Kingma, D. P., \& Ba, J. L. (2015). Adam: A method for stochastic optimization. 3rd International Conference on Learning Representations, ICLR 2015 - Conference Track Proceedings, 1-15. 
Kulkarni, A., Chong, D., \& Batarseh, F. A. (2020). Foundations of data imbalance and solutions for a data democracy. In Data Democracy: At the Nexus of Artificial Intelligence, Software Development, and Knowledge Engineering. Elsevier Inc. https://doi.org/10.1016/B978-0-12-818366-3.00005-8

Le, X. H., Ho, H. V., Lee, G., \& Jung, S. (2019). Application of Long Short-Term Memory (LSTM) neural network for flood forecasting. Water (Switzerland), 11(7). https://doi.org/10.3390/w11071387

Penzel, T., Moody, G. B., Mark, R. G., Goldberger, A. L., \& Peter, J. H. (2000). Apnea-ECG database. Computers in Cardiology, 255-258.

Purwowiyoto, S. L. (2018). Obstructive Sleep Apnea dan Gagal Jantung. YARSI Medical Journal, 25(3), 172. https://doi.org/10.33476/jky.v25i3.364

Shen, G., Tan, Q., Zhang, H., Zeng, P., \& Xu, J. (2018). Deep learning with gated recurrent unit networks for financial sequence predictions. Procedia Computer Science, 131, 895903. https://doi.org/10.1016/j.procs.2018.04.298

Singh, D., Vinod, K., \& Saxena, S. C. (2004). Sampling frequency of the RR interval time series for spectral analysis of heart rate variability. Journal of Medical Engineering and Technology, 28(6), 263-272. https://doi.org/10.1080/03091900410001662350

Song, C., Liu, K., Zhang, X., Chen, L., \& Xian, X. (2016). An Obstructive Sleep Apnea Detection Approach Using a Discriminative Hidden Markov Model from ECG Signals. IEEE Transactions on Biomedical Engineering, 63(7), 1532-1542. https://doi.org/10.1109/TBME.2015.2498199

Srivastava, N., Hinton, G., Krizhevsky, A., Sutskever, I., \& Salakhutdinov, R. (1993). Dropout. A Simple Way to Prevent Neural Networks from Overfittin. Physics Letters $B$, 299(3-4), 345-350. https://doi.org/10.1016/0370-2693(93)90272-J

Varon, C., Caicedo, A., Testelmans, D., Buyse, B., \& Van Huffel, S. (2015). A Novel Algorithm for the Automatic Detection of Sleep Apnea from Single-Lead ECG. IEEE Transactions on Biomedical Engineering, 62(9), 2269-2278. https://doi.org/10.1109/TBME.2015.2422378

Wang, T., Lu, C., Shen, G., \& Hong, F. (2019). Sleep apnea detection from a single-lead ECG signal with automatic feature-extraction through a modified LeNet-5 convolutional neural network. PeerJ, 2019(9), 1-17. https://doi.org/10.7717/peerj.7731 